\title{
Společnost Josepha von Öttla v městském divadle v Olomouci (1780-1783)
}

\author{
Jiří Štefanides
}

\begin{abstract}
Abstrakt
V roce 1770 bylo v Olomouci zřízeno městské německy hrající divadlo. Studie popisuje tř́leté období pronájmu divadla společnosti Josepha von Öttla v letech 1780-1783, k němuž se výjimečně dochovaly prameny se soupisem repertoáru a členstva. Analýza prokázala, že Öttlova společnost, provozující činohry, singspiely a pantomimy, prezentovala v Olomouci, tehdejší pohraniční pevnosti rakouské monarchie, ambiciózní osvícenský divadelní program, odrážející aktuální dramaturgii vídeňského Burgtheateru. Obdobně cenné prameny se dochovaly až k roku 1796 za ředitele Carla Haina.
\end{abstract}

\section{Klíčová slova}

Joseph von Öttl, Karl von Pallestrazzi, Olmütz, městské divadlo, německojazyčné divadlo, osvícenství

\begin{abstract}
Abstrakt
In 1770, German-language municipal theatre was established in Olomouc. The study describes the three-year tenancy (1780-1783) of the theatre building by the company of Joseph von Öttl, to which materials including the list of repertoire and the company members survived. An analysis shows that Öttl's company, producing drama, singspiels, and pantomimes, run ambitious Enlightenment theatre, reflecting the contemporary dramaturgy of Viennese Burgtheater, in Olomouc, a fortified city on the borders of the Austrian monarchy. Equally valuable materials can later be found only about the director Carl Hain, who managed the theatre in 1796.
\end{abstract}

\section{Keywords}

Joseph von Öttl, Karl von Pallestrazzi, Olmütz, municipal theatre, German-language theatre, Enlightenment 
V polovině 18. století představovala olomoucká pevnost jedno z nejvýznamnějších míst obrany rakouské monarchie. Když se v roce 1758 ubránila obléhání Prusů, její vojenský význam se zdál být potvrzen i pro budoucno. To ovšem zároveň rozhodlo o tom, že rozvoj města se na jedno století takřka zastavil. Pod městskými hradbami byly do vzdálenosti 800 metrů při přestavbě pevnosti zbourány všechny předměstské stavby, město bylo obehnáno věncem bastionů a vodními příkopy. Z hlediska národnostního se Olomouc jevila jako německé město. Mezi jejími obyvateli převažovalo důstojnictvo, duchovní a studenti.

Poměrně konzervativní ovzduší pevnostního sídla však kupodivu nebránilo už v roce 1746 vzniku první soukromé učené společnosti v rakouské monarchii, Societas eruditorum incognitorum. Zasloužil se o ni olomoucký měštan Josef Petrasch a měla co do činění i s divadlem - jejím členem byl mimo jiné německý filolog Johann Christoph Gottsched, propagátor pravidelného dramatu oproti barokní improvizaci, a sám Petrasch psal dramatické texty. I když společnost po roce 1750 s odchodem Petrasche zanikla, byl to první projev probouzejícího se osvícenství v Olomouci.

Z hlediska divadelního patřila Olomouc už v průběhu 18. století k nejvýznamnějším štacím na Moravě a ve Slezsku. V letech 1744-1770 se pravidelně hrálo v domě U Černého orla na Dolním náměstí. ${ }^{1}$ Ve dvoře tohoto zájezdového hostince nechal jeho tehdejší majitel Anton Müller vybudovat dřevěný sál s galerií, který pronajímal kočujícím společnostem. Zde se odbyly četné divadelní produkce vrcholícího baroka. Když pak během šedesátých let toto soukromé divadlo stavebně chátralo, začalo se město Olomouc zabývat myšlenkou zřízení vlastního divadelního sálu. Ten byl nakonec zabudován do prvního patra nad masnými krámy v domě čp. 35, který stál rovněž na Dolním náměstí, v těsném sousedství tehdy už bývalého Müllerova domu. Stalo se tak v roce 1770 a divadlu se dostalo honosného a moderního názvu: Königlich-städtisches Nationaltheater in Olmütz (HAVLÍČKOVÁ, PRACNÁ a ŠTEFANIDES 2013: 88-93).

Po Brnu (založeno 1733) a Opavě (po roce 1745) to bylo třetí nejstarší městské divadlo na Moravě a ve Slezsku. V prvním desetiletí jeho existence se potýkáme s nedostatkem pramenů včetně olomouckých archivů. S pomocí práce Christiana d'Elverta sestavíme alespoň přehled jmen čtrnácti ředitelů společností, kteří si pravděpodobně zdejší městské divadlo do roku 1780 pronajali (ELVERT 1852: 141). Zmínky o působení v Olomouci obsahují hesla významnějších divadelních direktorů v německých a rakouských encyklopediích - našemu prostředí je nejbližší a nejmladší česko-rakouský lexikon, který vydala Rakouská akademie věd (JAKUBCOVÁ a PERNERSTORFER 2013). Postrádáme však prameny přímo se vztahující k olomouckým představením. Ve Státním okresním archivu v Olomouci se k tomuto období nedochovaly zápisy z jednání magistrátu, celé první desetiletí městského divadla v Olomouci je tak pro nás mlčenlivé. Přitom právě sedmdesátá léta byla obdobím nesmírně důležitým: tehdy i v Olomouci končila epocha barokního divadla, kterou střídaly nové tendence osvícenské, jak ostatně naznačuje už první název zdejšího městského divadla. Teprve až v případě Öttlovy společnosti máme k dispozici její almanach, který obsahuje kompletní repertoár odehraný v Olo- 
mouci v roce 1781 (VKOL 1781) - jeho analýza tedy bude jedním z témat této studie. Dalším cenným pramenem je smlouva mezi společností a městem o tř́letém pronájmu městského divadla, kterou Öttl vyjednal na jaře 1781 (SOAO 1781a). Vypovídá mnohé o tehdejším stavu, úrovni a organizaci divadelního provozu ve městě. Poslední přímý pramen, který máme k dispozici a který dosud nebyl v kontextu našeho tématu v literatuře reflektován, je zastoupení olomouckého divadla v jedné z prvních divadelních ročenek, jež vycházely v Gothě. Nájemce Öttlovy koncese Karl von Pallestrazzi obeslal ročenku podrobným soupisem členstva souboru v první polovině sezony 1782/1783 (OLLMÜTZ 1782).

Badatel zároveň nadále čelí některým zásadním nejistotám a nejasnostem. Předně jméno ředitele Josepha von Öttla ${ }^{2}$ se v odborné literatuře a v soudobých pramenech vyskytuje pouze sporadicky. V některých pracích bibliografického charakteru či v encyklopediích zejména rakouského a německého původu je sice jeho jméno zaznamenáno, ale vždycky se vztahuje pouze k jeho jedinému olomouckému pobytu v roce 1781 (PIES 1973: 269; ULRICH 1997: 1357). Lze předpokládat, že tento problém nějak souvisí se skutečností, že Öttl během olomouckého pobytu v květnu 1781 nečekaně zemřel. Koncesi a smluvní povinnosti v Olomouci převzala jeho žena, která posléze vedení společnosti svěřila muži, jenž se podepisoval jako Karl Edler von Pallestrazzi. Ten prokazatelně řídil společnost ještě v sezoně 1782/1783, ale po odchodu z Olomouce se i jeho jméno v pramenech ztrácí - patrně nepokračoval ve vlastní ředitelské kariéře. V následující sezoně 1783/1784, alespoň v její první části, působil pak v Olomouci ředitel Karl von Morocz, jenž si údajně pronajal poslední třetí sezonu, kterou měla v Olomouci zajištěnu původní smlouvou vdova po řediteli Öttlovi (ELVERT 1852: 141). Spolehlivě neznáme ani přesný začátek působení Öttlovy společnosti v Olomouci. Zmíněný almanach uvádí první představení ke dni 21. ledna 1781, podle d'Elverta ale už v říjnu 1780 Öttl získal jednoletý pronájem městského divadla. Bohužel Christian d'Elvert jen málokdy odkazuje na prameny, opíral se zejména o výzkum v brněnských archivech, ale zdá se, že jeho informace jsou v tomto případě spolehlivé (ELVERT 1852: 141). Posloupnost ředitelů v olomouckém divadle do roku 1780 potvrzují i jiné novější zdroje, s nimiž se d’Elvert nedostává do rozporu.

\section{Olomoucký divadelní kontext}

Jak už bylo řečeno, o charakteru divadelních představení v Olomouci v letech 1770-1780 chybí bližší informace, z nichž bychom mohli spolehlivě odvodit a popsat proces přechodu od barokních divadelních konvencí k naplňování cílů osvícenských. Své úvahy můžeme tedy odvíjet pouze z nepřímých, velmi kusých poznatků, které zaznamenávají prameny a literatura o zdejších ředitelích na jiných štacích před sezonami v Olomouci nebo po nich.

2 V dosavadní literatuře se uvádí spíše podoba jména Joseph von Oettl. Rozhodli jsme se pro variantu Öttl z toho důvodu, že se tak vlastnoručně podepsal sám ředitel a posléze i jeho manželka na smlouvě s magistrátem. 
Zdá se, že po dobudování městského divadelního sálu se do konce roku 1770 nikdo o jeho pronájem neucházel. Provoz nového městského divadla pravděpodobně zahájil až v roce 1771 spojený soubor dvojice ředitelů Karla Josepha Schwertbergera a Johanna Michaela Brennera. Prvně jmenovaný Olomouc dobře znal, hrál zde poprvé už v roce 1756 v hostinci U Černého orla a pak ještě několikrát, ale jeho repertoár není znám. Provozoval také loutkové divadlo (JAKUBCOVÁ a PERNERSTORFER 2013: 619-620). Rovněž Brenner už byl dříve v Olomouci. V jeho repertoáru se vyskytovaly barokní hauptakce a italské komedie, ale občas i pravidelná dramata (JAKUBCOVÁ a PERNERSTORFER 2013: 70-72). V témže roce 1771 přijela do Olomouce z Brna ještě společnost Kajetana Augustina Schaumberga. V Brně tento ředitel provozoval mimo jiné singspiely spojené s inscenační praxí velké barokní opery a také pantomimy. Podle Margity Havlíčkové jeho brněnské působení představovalo poslední fázi barokního divadla v Brně (HAVLÍČKOVÁ 2005: 224). Zcela bez informací, pokud se jedná o repertoár, jsme v případě dalších tř́ společností, které v Olomouci hrály v roce 1772: jedná se o ředitele Franze Alfaniho, Theresii Nicoliniovou a Christiana Wetzela. V roce 1772 se v Olomouci zastavil také Andreas Fiedler, ve svém repertoáru měl ještě v témže roce v Brně barokní burlesky (JAKUBCOVÁ a PERNERSTORFER 2013: 186). Jestliže se v městském divadle v jediném roce 1772 vystřídaly čtyři společnosti, je zřejmé, že šlo ještě o obvyklé kratší stagiony, nikoliv o stabilní pronájem divadla jednomu řediteli na celou sezonu.

V následujícím roce 1773 si pronajal městské divadlo v Olomouci Mathias Joseph Einziger, který zde hrál v hostinci U Černého orla už v roce 1767. Einziger pocházel z Trnavy a v pramenech bývá označován jako nejlepší Hanswurst v Uhrách. Ještě v sedmdesátých letech pěstoval barokní burlesky, v roce 1777 bavil brněnské publikum v letní boudě kasperliádami, ale zařazoval už i fixované texty Voltaira, Stephanie staršího a Stephanie mladšího ad. (JAKUBCOVÁ a PERNERSTORFER 2013: 171-172).

Poslední společností, která v Olomouci vystupovala a o jejímž repertoáru jsou alespoň obecné informace, byla v sezoně 1775/1776 společnost Johanna Matthiase Menningera. Pravděpodobně ještě v této době v jejím programu převažoval barokní repertoár, sám ředitel byl od svého hereckého mládí oblíbeným Hanswurstem. V Olomouci byl u společnosti také Johann La Roche, jeden $\mathrm{z}$ tehdy nejpopulárnějších představitelů Kasperla (JAKUBCOVÁ a PERNERSTORFER 2013: 422-426). Po Menningerovi a před Öttlovou společností hráli v Olomouci ještě ředitelé Wolfgang Rößl (1776-1778) a společně Anton Pauli a Johann Baptist Mayer (1778-1780) - o jejich repertoáru a o charakteru jejich divadelních produkcí však nemáme žádné informace (HAVLÍČKOVÁ, PRACNÁ a ŠTEFANIDES 2013: 106).

\section{Profil společnosti Josepha von Öttla v roce 1781}

V druhé polovině 18. století vycházel periodický tisk jen v největších sídlech, navíc ne vždy reflektoval divadelní život. Pokoušíme-li se zjistit to základní, totiž odehraný repertoár, ideálním pramenem jsou almanachy společností, vydávané na konci kalendářního 
roku, které zpravidla soupis her uvedených v daném místě a uplynulém roce obsahují. I ty se však v této době dochovaly spíše výjimečně. Ten, kterým se budeme zabývat, vyšel v Olomouci na konci roku 1781. Podle bibliografa Paula S. Ulricha z Berlína, který mimo jiné sestavil úplný soupis dostupných almanachů pro české země, je tato olomoucká památka u nás druhá nejstarší. ${ }^{3}$ Plným názvem: Theater-Taschenbuch. Von 21. Jenner bis Ende Dec. 1781 aller von der allhiesigen deutschen Schauspielergesellschaft in Ollmütz aufgeführten Schau- und Singspielen. Zum Neuen Jahrs-Geschenke zusammengetragen (VKOL 1781). Na čtrnácti stranách je nejprve uveden soupis členů společnosti s charakteristikou hereckého oboru, aktuální v době vydání almanachu, tedy v prosinci 1781 (v oddílech Namen der Schauspieler in ihrem Fache - Schauspielerinnen - Kinderrollen - Musik und Opern Kompositeur). Následuje soupis odehraného denního repertoáru po jednotlivých měsících v roce (Verzeichniß aller aufgeführten Schau- und Singspielen). Na závěr je uveden přehled členů souboru, kteří odešli během roku (Abgegangen) a lakonická informace o úmrtí Josepha von Öttla. Jako ředitel společnosti (Entrepreneur) je jmenován Karl Edler von Pallestrazzi.

Soupis představení prozrazuje, že společnost hrála v Olomouci ve dvou obdobích, oddělených kratší přestávkou. První část sezony trvala od 21. ledna do 26. února (jeví se tak jako dokončení sezony 1780/1781), druhá od 16. dubna do 30. prosince 1781. V mezidobí se uskutečnily pouze dvě hudební akademie, které uspořádal člen společnosti Johann Georg Anton Mederitsch, kapelník a hudební skladatel, a to ve dnech 29. března a 6. dubna. Zdá se, že tato přestávka zahrnula závěr masopustního období, kdy se v divadle konaly plesy a zábavy, a skončila pravděpodobně s noremními dny. ${ }^{4}$ Jako ne zcela obvyklou okolnost zaznamenejme, že společnost vytrvala v Olomouci i přes léto, což byl vždy čas pro divadlo nepřívětivý. Zpravidla se i soubory z městských divadel vydávaly na letní putování, vyhledávaly lázeňská města (zejména později, v 19. století), někdy dokonce ředitel na léto společnost rozpustil. ${ }^{5}$

Almanach obsahuje „moderně“ pořízený přehled repertoáru: není to soupis pouze titulový, jedná se o zápis datovaného denního repertoáru, místy i s doplňujícími informacemi, takže poskytuje poměrně konkrétní obraz divadelního programu společnosti. Postrádáme zde pouze jeden, ale zato důležitý údaj: totiž jméno dramatika či skladatele uvedeného kusu. Museli jsme se tedy pokusit o jejich určení komparací se známým repertoárem jiných divadel a souborů. V tomto případě se jako nejvhodnější jevil soupis repertoáru vídeňského Burgtheateru od roku 1776 (ALTH a OBZYNA 1977), případně soupis repertoáru brněnského divadla (WURMOVÁ 1996). Ke spolehlivosti určení autora touto metodou velmi přispívá zápis plného názvu hry či singspielu i s rozvinutým

3 Jen o čtyři roky starší je Taschenbuch von der Prager Schaubühne auf das Jahr 1778, vydaný v Praze téhož roku. Viz ULRICH, Paul S. Deutschsprachiges Theater in Tschechien (1777-1918). Bd. 1. (Pracovní verze před vydáním.)

4 A mezitím, 7. dubna 1781, také Öttl podepsal s městem smlouvu o pronájmu městského divadla na tři sezony (SOAO 1781a).

5 Celoroční pobyt v Olomouci patrně usnadňovala zdejší praxe: protože diváky v sále městského divadla nad masnými krámy obtěžoval zápach, prostupující podlahou, na jaře a v létě byla na Dolním náměstí postavena jednoduchá dřevěná, ale vzdušná aréna. 
podtitulem a s žánrovým určením, včetně počtu jednání (aktů). Přesto to není úkol jednoduchý: Öttlova společnost uvedla v Olomouci během roku 1781 ve 135 večerech celkem 115 činoherních titulů (často dva v jednom večeru), deset různých titulů označených jako singspiel, jeden melodram a několik dalších menších produkcí. Po provedené komparaci s dobovým repertoárem pochybnosti o autorství provázejí zhruba čtvrtinu činoherních titulů, podobně tomu je po ověření autorství u singspielů. ${ }^{6}$ Určit se nepodařilo autory pantomim-harlekyniád a jediného představení označeného jako italská pantomima.

\section{Činoherní repertoár}

První okruh autorů činoher je spojen s reformním úsilím osvícenských divadelníků v německých zemích. K dílu Gottholda Ephraima Lessinga se společnost během roku 1781 vrátila třikrát: uvedla hry Die Juden, Minna von Barnhelm a Emilia Galotti (možná i proto, že v únoru téhož roku Lessing zemřel). Mezi Lessingovy vrstevníky a spolupracovníky ještě patřili Christian Felix Weisse (v Olomouci uvedena jeho starší veselohra z roku 1851 Die Poeten nach der Mode), Christian Fürchtegott Gellert (Die junge Witwe), Gustav Friedrich Grossmann (Die Feuersbrunst) a Johann Christian Brandes (Der Graf von Olsbach, Die Mediceer, Trau, schau, wem!). Z mladší generace německých divadelníků spojených s osvícenstvím uvedla Öttlova společnost i dvě hry Johanna Jacoba Engela (Der Edelknabe a Der dankbare Sohn). Dalšími dramatiky hlásícími se k osvícenským ideálům, ovšem rakouského původu, byli Heinrich Ferdinand Möller (hrál se Der Graf von Walltron) a představitel katolického osvícenství Cornelius Hermann von Ayrenhoff (Der Postzug oder die noblen Passionen, Alte Liebe rostet wohl). Zejména s českými zeměmi spojil svou dráhu herec, dramatik a překladatel Franz Joseph Fischer (Alles aus Freundschaft). Zaznamenáme i dvě jména patřící k hnutí Sturm und Drang: Friedricha Maximiliana Klingera (Die Zwillinge), a dokonce Johanna Wolfganga Goetha (tragédie Clavigo). V repertoáru se často vyskytovala také jména nejmladší tehdejší generace německy púšících dramatiků, k ní patřili Joseph Bernhard Pelzel (Yariko), Joseph Marius Babo (Das Winterquartier in Amerika), Johann Friedrich Schink (Gianetta Montaldi), Johann Rautenstrauch (Jurist und Bauer) a dalš́́. Nejpopulárnějším autorem té doby ovšem byl rakouský dramatik, operní libretista a překladatel Gottlieb Stephanie mladší, během roku 1781 se v Olomouci hrálo osm jeho veseloher a dva singspiely s jeho librety. ${ }^{7}$

Öttlova společnost se ovšem nevyhýbala ani dramatice $\mathrm{z}$ jiných národních okruhů, zejména textům francouzské a anglické provenience. $\mathrm{V}$ případě překladů z francouzštiny dávala přednost soudobým autorům: byli mezi nimi Louis-Sébastien Mercier, François-Thomas d'Arnaud, Charles Collé, Charles-Georges Fenouillot de Falbaire a Jacques-Marie Boutet Monvel. Za zaznamenání stojí uvedení děl Jeana

6 V určení operních titulů došel nejdále Jiřri Kopecký (KOPECKÝ 2012: 24-27).

$7 \quad$ Z veseloher to byly např́klad Deserteur aus Kindesliebe, Der Neugierige, Das Loch in der Thüre aj. 
Jacquese Roussseaua („eine lyrische Handlung“ Pygmalion a Grossmannova veselohra podle Roussseauovy předlohy Henriette, oder sie ist schon verheuratet), zejména pak ale Beaumarchaisův Der Barbier von Sevilien, oder die unnüze Vorsicht. Dočkal se dokonce tří představení, což znamenalo v př́ípadě činoherního repertoáru velký divácký úspěch. Anglická dramatika pocházela spíše ze starších dob, hrála se veselohra Das Landmädchen, dokonce ještě od Williama Wycherleyho (zemřel v roce 1716), od soudobých dramatiků byly předvedeny hry Georga Colmana, Richarda Cumberlanda a zejména od významné postavy anglického divadla 18. století Davida Garricka. Nejvíce ale v repertoáru společnosti zaujmou hned čtyři shakespearovské tituly: Othello, der Mohr von Venedig, oder das Schnupftuch, Hamlet, Prinz von Dännemark, Romeo und Julie a Macbeth - ten se hrál dokonce dvakrát. Nevíme ovšem, zda šlo o překlady Shakespearových textů, nebo o autorské adaptace německých autorů. ${ }^{8} \mathrm{Z}$ méně zastoupených italských autorů se pětkrát hrály Goldoniho komedie a jednou dílo Carla Gozziho (Juliane von Lindorak).

Soupis představení za rok 1781 je zajímavý ještě z jednoho ohledu. Se Shakespearovými tragédiemi začal ještě Öttl, ale jinak velká většina překladů byla uvedena až v druhé polovině roku, po Öttlově úmrtí. Byl to tedy Pallestrazzi, který podstatně rozšíril program společnosti a omezil poměrně jednostrannou orientaci na německy píśící autory. U obou je ale patrná dokonalá orientace v soudobé dramaturgii, jak ji ve své době prezentoval především vídeňský Burgtheater - při tak velkém množství v Olomouci odehraných titulů to představovalo úctyhodnou část repertoáru Burgtheateru za několik posledních sezon. Samozřejmě tato praxe, vynucená nepochybně stále nevelkým okruhem potenciálních diváků pevnostního města, musela mít neblahý vliv na úroveň představení - zejména značný počet činoherních titulů se odbyl v jediném představení.

Zcela jistě však můžeme učinit jeden důležitý závěr: Öttlova - Pallestrazziho společnost představovala $\mathrm{v}$ roce 1781 soubor, který už neměl nic společného s dědictvím barokního improvizovaného divadla. Její repertoár prezentoval pevné dramatické texty, které $\mathrm{v}$ řadě př́padů realizovaly osvícenské představy o moderních funkcích divadla. Ozvěny komických typů komedie dell'arte mohly zaznít v komediích Goldoniho, a pak také při harlekyniádách. $\mathrm{V}$ tomto př́ípadě se ovšem nejspíše jednalo o obecně oblíbené pantomimické produkce, v nichž byl Harlekýn už pouze divadelní postavou, nikoliv spojen s hercem představujícím typ barokní komedie dell'arte. ${ }^{9}$ Můžeme konstatovat, že nejpozději v roce 1781 už divadelní život v Olomouci patřil do nové doby.

8 O několik let dřive se ve Vídni hrála Weisseho úprava Romea a Julie, existovala také Schröderova adaptace Hamleta a Brockmannova verze Othella.

9 A sotva mohlo jít už o tzv. dějový balet spojený s psychologizací postav, který přinesla osmdesátá léta jako jeden z produktů osvícenských reforem. 


\section{Hudební divadlo}

Také zpěvoherní repertoár prozrazuje, že Öttlova společnost se orientovala ve slohových proměnách doby - zřetelně nastoupila cestu od italské barokní opery k německému singspielu. A pokud uváděla jinojazyčná díla, vždy pouze v němčině. ${ }^{10} \mathrm{~V}$ německé verzi např́ḱlad sehrála dílo italského skladatele Egidia Duniho Das Milchmädchen, oder die beyden Jäger. Rovněž v němčině se konalo jediné představení Die Marquisin, oder der übel angebrachte Stolz Floriana Leopolda Gassmanna, skladatele italského školení, který byl v letech 1772-1774 u vídeňského dvora jako dvorní kapelník. ${ }^{11}$ Orientace na novou „národní“ operní tvorbu samozřejmě nutila ředitele vyhledávat co nejaktuálnější novinky. Mezi ně patřilo dílo rakouského skladatele a kapelníka Ignaze Umlaufa Die pücefarbnen Schuhe, oder die schöne Schusterinn. Vzniklo na libreto Johanna Gottlieba Stephanie mladšího v roce $1779 .{ }^{12}$ Ještě o rok později byl poprvé uveden singspiel opět rakouského skladatele Josefa Martina Ruprechta Was erhält die Männer treu? na libreto Ludwiga Eduarda Zehnmarka. V Olomouci se hrál dvakrát v říjnu a listopadu 1781. Singspiel Die Liebe auf dem Lande Johanna Adama Hillera, pokládaného za jednoho ze zakladatelů německého singspielu, byl staršího původu (z roku 1768), ale hrál se čtyřikrát. U dvou děl zaznamenáme autory patrně českého původu. Už starší jednoaktovku Der Schlosser složil pravděpodobně Josef Kohout působící ve Francii. Byla velmi populární a hrála se v mnoha divadlech ještě na začátku 19. století, prodělávala však různé autorské úpravy. V Olomouci byla uvedena dvakrát. Melodram Ariadne auf Naxos měl premiéru v roce 1775 a hudbu k textu Johanna Christiana Brandese napsal Jiří Antonín Benda. I toto dílo mělo v Olomouci dvě představení.

Ve většině případů se jednalo o singspiely jedno až dvouaktové a byly uváděny zpravidla společně s činoherní jednoaktovkou, případně s produkcemi manželů Seveových nebo rodiny Hasenhutových. O způsobu a úrovni provedení se nemáme o co opřít. Ani almanach z roku 1781, ani prezentace společnosti v ročence na rok 1783 (OLLMÜTZ 1782: 272-274) se nezmiňují o vlastních hudebnících společnosti, není tedy zřejmé, kdo zajištoval hudební doprovod. Soubor neměl specializované operní zpěváky, část herců vystupovala v singspielech i v činohrách. Můžeme se domnívat, že jednodušší hudební formy teprve se utvářející německé operní tradice ve srovnání s vyspělou italskou operou (a snad tedy i kladoucí menší nároky na pěvecké a instrumentální výkony) usnadňovaly Öttlově společnosti uvádění soudobé opery na přijatelné úrovni.

10 V ročence Theater-Kalender auf das Jahr 1783 dokonce Pallestrazzi pokládal za důležité vložit do soupisu členů společnosti toto upozornění: „Diese Gesellschaft giebt vorzüglich große, wohl aus dem Italienischen als auch Französischen übersetzte Singspiele“ (OLLMÜTZ 1782: 273).

11 Libreto napsal podle textu Carla Goldoniho Marco Coltellini. Není bez zajímavosti, že, podle zjištění Jiř́ího Kopeckého, bylo dílo poprvé uvedeno v roce 1770 v Uničově (Mährisch Neustadt) (KOPECKÝ 2012: 26). V roce 1771 se pak hrálo italsky v Burgtheatru a teprve v roce 1786 německy v divadle v Leopoldstadtu.

12 V Olomouci byla ještě uvedena komická opera Die Sklavinn neznámého skladatele, pro niž Stephanie mladší volně přepracoval italské libreto. 


\section{Soubor}

Almanach uvádí na konci roku 1781 celkem dvacet tři jmen herců a zpěváků (včetně ředitele, kapelníka a dvou dětí), kteří v té době byli v souboru, a devět jmen těch, kteří během roku odešli. U každého jména přítomných členů je pojmenován obor, pro nějž byl dotyčný angažován, případně další funkce v divadle (napověda apod.). Bohužel zde najdeme pouze př́jmení bez křestního jména, u dam je navíc uveden údaj slečna - paní. Identifikace aktérů je tedy rovněž svízelná a daří se jen u asi čtvrtiny jmen. Přitom znalost individuálních profilů herců a zpěváků a jejich migrace ve středoevropském prostoru před i po olomouckém pobytu je pro badatele nesmírně důležitá. Byli vždy nositeli určitých dobových konvencí, stylových tendencí, prošli malými i velkými divadly, byli těmi tvůrci, kteří v časoprostoru nesmírně rychle a aktuálně přenášeli nové divadelní systémy. Pro potvrzení toho se pokusíme přiblížit alespoň těch několik postav olomouckého jeviště známých z roku 1781.

\section{Franz Vasbach s manželkou Barbarou Vasbachovou}

Jako člena společnosti Josepha von Öttla v Olomouci v roce 1781 identifikoval Franze Vasbacha (narozen 1758, zemřel po roce 1812, psán také Vassbach, Vaßbach) už AdoIf Scherl (PROCHÁZKA 1988: 544-545). Jeho stopa v dějinách divadla v rakouských zemích je poměrně výrazná. Poprvé je zaznamenáno jeho angažmá u společnosti Franze Scherzera v roce 1779, s níž hrál ve vídeňském Josefstadtu v tzv. Bauernfeindovském sále. Po olomouckém pobytu se objevil až v sezoně 1786/1787 ve spojených vídeňských dvorních divadlech, v letech 1788-1791 působil s ředitelem Karlem Wahrem v Nosticově divadle, v letech 1793-1794 byl dokonce ředitelem Vlastenského divadla - Vaterländisches Theater. (JAKUBCOVÁ a PERNERSTORFER 2013: 713-714.). V olomouckém almanachu je jeho herecký obor vymezen takto: komičtí staří, pedanti, sedláci, v singspielech zpíval menší komické role, zároveň zastával funkci napovědy. Manželka Barbara (kolem 1758-1804, rozená Fölklová) byla jednou ze šesti dam, které jsou jmenovány v souboru na konci roku 1781. V Olomouci zastávala vedlejší role.

\section{Franz Xaver Seve s manželkou Susane Seveovou}

Produkce manželů Seveových (příjmení psáno také Sewe) zaznamenává almanach pouze v lednu a v únoru 1781, to znamená, že od společnosti odešli před jarní přestávkou. Oba jsou zapsáni v dějinách divadla v českých zemích. Franz Seve (1753, resp. 1754-1791), tanečník a baletní mistr, byl z manželského páru postavou významnější. Od roku 1773 byl členem vídeňského Burgtheatru, poté působil u společnosti Karla Wahra v Prešpurku a v Divadle v Kotcích v Praze. V letech 1784-1786 byl tanečníkem a tanečním mistrem v Nosticově divadle a v roce 1786 se stal jedním ze čtyř zakladatelů Vlastenského divadla - Vaterländisches Theater v Praze. Se Susane Franckovou (životní data neznáme, psána také 
Susanna) se Seve oženil po př́chodu do Prahy v roce 1779 (JAKUBCOVÁ a PERNERSTORFER 2013: 635-637). V olomouckém almanachu z roku 1781 jsou manželé Seveovi zmíněni mezi těmi, kteří během roku od společnosti odešli, chybí tedy u jejich jmen charakteristiky hereckých oborů. Během ledna a února je v soupisu odehraného repertoáru zmíněno celkem osm jejich tanečních vystoupení, která byla někdy součástí představení, vyplňovala přestávku nebo se uskutečnila po skončení představení. Dá-li se to tak říci, Seveovi předváděli taneční produkce s národními prvky, což jistě konvenovalo dobovým osvícenským představám. Můžeme tak usuzovat z lapidárních charakteristik: „englisch Solo“, „ein Cosakisches National Pas de Deux“, „das National-Cosaken Pas de Deux“, „ein ungarisch Pas de Deux“, ale také „ein Strassburger Pas de Deux“. Při posledním vystoupení v Olomouci 26. února „tanzte Hr. Seve mit seiner Frau englisch “. ${ }^{13}$

\section{Hasenhut a jeho děti}

Pod označením „Hrn. Hasenhuts Kinder“ almanach zaznamenal pět pantomimických vystoupení, první 19. dubna (tedy brzy po obnovení představení na jaře, to už u společnosti nebyli manželé Seveovi), poslední 30. září. Téměř jistě se jednalo o Josepha Hasenhuta (1736-1795) a jeho dva syny, Philippa (1763-1829) a Antona (1766-1841). Joseph Hasenhut byl ve své době poměrně známý herec. V letech 1776-1779 byl rovněž angažován u společnosti Franze Scherzera v Josefstadtu. U ní ztělesňoval komickou postavu Hanskaspara - podle svědectví jeho syna Antona v ní spojoval rysy Bernardona a Kaspara (BLÜMMEL a GUGITZ 1925: 277). Z obou synů se u divadla více prosadil právě mladší Anton. ${ }^{14}$ Když Hasenhutovi přišli do Olomouce, otec byl stár 45 let a už dva roky byl vdovcem. Se svými syny stř́idal angažmá u různých souborů, v letech 1781-1782 vystupovali také v Brně (JAKUBCOVÁ a PERNERSTORFER 2013: 751). Charakter jejich produkcí v Olomouci lze popsat pouze přibližně. Ve všech případech se jednalo pravděpodobně o nerozsáhlá komická pantomimická vystoupení, která měla podobu doprovodu k jiným představením („eine Pantomime in 1. Aufz."), zpravidla veseloherním. Badatel ovšem čelí několika otázkám. Všechna vystoupení „Hasenhutových dětí“ byla označována jako „Terzetto“, Josepha Hasenhuta však, pokud je známo, doprovázeli pouze dva synové. Je ovšem možné, že vystupovali společně s otcem. V době pobytu Hasenhutových v Olomouci uvedla společnost také pět tzv. harlekyniád a můžeme se důvodně domnívat, že v těchto pantomimách ztělesňoval Harlekýna právě Joseph Hasenhut, s ohledem na jeho předchozí herecké zkušenosti. Např́ílad 19. dubna po představení jednoaktové veselohry Der Blinde aus

13 Manžele Seveovy v Olomouci ztotožnil s Franzem Xaverem a Susane Adolf Scherl (PROCHÁZKA 1988: 435-436). Muzikolog Jiří Mikuláš se ale domnívá, že se jednalo o bratra Josepha s jeho manželkou. Ve své studii však neuvádí pramen, o který se opírá (MIKULÁŠ 2002: 89). Jeho tvrzení převzala Božena Brodská (BRODSKÁ 2006: 51).

14 Anton Hasenhut vytvořil postavu vídeňské lidové komedie zvanou Thaddädl, s níž byl v roce 1789 angažován do divadla v Leopoldstadtu. V letech 1803-1819 vystupoval v Theater an der Wien. Viz (HANSEN 1969: 31). 
Leichtgläubigkeit (podle francouzské předlohy zpracoval Mathias Jung) následovala jednoaktová pantomima Arlequins Skellet „mit einem dazu verfertigten Terzetto von den Hasenhutischen Kindern “. ${ }^{15}$ Jistou pochybnost také vzbuzuje označení „Hasenhutovy děti“: v té době bylo Antonovi patnáct a Philippovi dokonce osmnáct let. A ještě jeden otazník: poslední vystoupení 30. září se uskutečnilo po více než třech měsících (tehdy na závěr večera tančily „Herrn Hasenhuts Kinder Terzetto, gennannt die Unterhaltung auf dem Lande“). Jako možné se nabízí vysvětlení, že Hasenhutovi pouze přijížděli do Olomouce k př́ležitostným vystoupením z Brna - kdyby ovšem Pallestrazzi v almanachu na konci roku 1781 neuvedl Hasenhutovy v kolonce Odešli, tedy jako bývalé angažované členy společnosti. Je ovšem velmi pravděpodobné, že Hasenhutovi vystupovali i jako herci v běžných představeních a pantomimy byly pouze jejich příležitostným př́nosem. Jejich nedlouhé působení v Olomouci v roce 1781 není v literatuře nikde zaznamenáno. ${ }^{16}$

\section{Johann Mederitsch}

Kapelník, hudební a operní skladatel Johann Georg Anton Gallus-Mederitsch (1752-1835) se časem vypracoval na poměrně známou osobnost spojenou nejen s divadlem. První bližší poznatky o jeho divadelním působení jsou spjaty s jeho pobytem rovněž u společnosti Franze Scherzera v Josefstadtu nejpozději od roku 1779. V Olomouci vytrval nejméně v letech 1781-1782 (možná už od podzimu 1780), poté působil ve Vídni a v Budapešti. Už u Scherzera v srpnu 1779 měla premiéru jeho opera Der redliche Verwalter (BLÜMMEL a GUGITZ 1925: 280-281). Ke konci 18. století napsali společně s Peterem von Winterem dvouaktovou operu Babylons Pyramiden; autorem libreta byl Emanuel Schikaneder (ANTONICEK 1975: 183). Byl autorem hudebního doprovodu k Shakespearovým hrám Macbeth, Hamlet a Bouře, skládal sonáty, symfonie a koncerty (KOMORZYNSKI 1904: 245-248). Muzikolog Jiří Kopecký vyslovil domněnku, že Mederitschova hudba mohla zaznít i při olomouckých představeních Macbetha a Hamleta, není ovšem jisté, zda ji měl už v Olomouci Mederitsch k dispozici. V soupisu olomouckých představení singspielů pak nacházíme jediný titul, který by bylo možné Mederitschovi autorsky připsat. ${ }^{17}$

15 Philipp Hasenhut se později uplatňoval jako tanečník-mim a jako autor scénářů pantomim, mezi nimi i harlekyniád. Není tedy vyloučeno, že byl autorem těchto produkcí už v Olomouci a v literatuře tato skutečnost není dosud zaznamenána.

16 Ve svých strojopisných Dějinách olomouckého divadla, doba nejstarší, se na základě almanachu o Hasenhutových zmiňuje i Jaroslav Čičatka, jeho nejistý výklad je ale zavádějící (ČLCČATKA 1955: 53).

17 Jiří Kopecký upozorňuje na to, že 30. června 1781 se v Olomouci hrál singspiel Der letzte Rausch. Dílo stejného názvu je v literatuře připisováno právě Mederitschovi, ale až od roku 1788 - je tedy možné, že olomoucké uvedení může dataci vzniku tohoto díla upřesnit (KOPECKÝ 2012: 26). 


\section{Karl Edler von Pallestrazzi}

Ačkoliv vedl olomoucké městské divadlo nejméně dva roky jako nájemce koncese Eleonory Öttlové, je nejvíce utajenou osobností v tomto příběhu. Jeho jméno není spojeno $\mathrm{s}$ žádným divadlem ani před Olomoucí, ani po skončení zdejšího pobytu. V bibliografických soupisech tištěných pramenů německé a rakouské provenience se jeho jméno vyskytuje výjimečně a právě jen v souvislosti s Olomoucí v letech 1781-1782. Nevíme, zda byl hercem či zda zastával jinou funkci v provozu divadla - v almanachu sám sobě připojil pouze označení „Entrepreneur“. Zdá se, že v Olomouci po Öttlově skonu řídil společnost, která byla konsolidovaná, dobře vybavená přinejmenším knihovnou soudobé dramatiky a snad i garderobou a dekoracemi, ale po odchodu z Olomouce zjevně nepokračoval vlastním ředitelským působením. Poslední jeho stopa je spojena s prezentací olomouckého souboru ve zmíněné ročence německých divadel vydané v Gothě k začátku roku 1783 (OLLMÜTZ 1782), tedy uprostřed sezony 1782/1783.

\section{Joseph Edler von Öttl s manželkou Eleonorou Öttlovou}

$\mathrm{S}$ informacemi o původním majiteli koncese a řediteli společnosti se nacházíme v obdobné situaci. Už jsme konstatovali, že jeho jméno se v německých a rakouských soupisech a bibliografiích tištěných pramenů objevuje rovněž pouze $\mathrm{v}$ souvislosti $\mathrm{s}$ jeho olomouckým pobytem. $\mathrm{S}$ jedinou cennou informací $\mathrm{v}$ dosavadní literatuře přišel Otto G. Schindler. Když se zabýval působením ředitele Franze Scherzera v Josefstadtu, zaznamenal, že Scherzer řešil dluh ve výši 2600 zlatých tím, že svému společníkovi přenechal někdy v létě 1780 celou garderobu a dekorace - a tím společníkem měl být Joseph von Öttl (JAKUBCOVÁ a PERNERSTORFER 2013: 598). ${ }^{18}$ To by tedy neznamenalo nic menšího, než že na podzim 1780 si Öttl založil společnost a zahájil, s dobrým vybavením na počátku její existence, vlastní ředitelskou dráhu. Pak by bylo velmi pravděpodobné, že první, a tedy i jeho poslední štací byla právě Olomouc. Naši hypotézu nepř́ímo posiluje znovu Schindler zjištěním, že Scherzer se už před rokem 1780 marně snažil získat pronájem olomouckého městského divadla - zdejší prostředí tedy znal a mohl Öttlovi poskytnout doporučující informace. ${ }^{19}$ Stejně jako u Pallestrazziho, ani v př́padě Öttla nevíme, zda byl hercem nebo zpěvákem. Ani manželka Eleonora, ač po jeho smrti nositelka koncese, není $\mathrm{v}$ almanachu uváděna jako členka souboru - pravděpodobně tedy nebyla $\mathrm{v}$ divadle aktivní.

V Olomouci se pak dochoval ještě jeden cenný pramen, naznačující alespoň částečně odpovědi na naše nedostatečné informace. $\mathrm{V}$ úmrtní matrice Vnitřní město pro období 1759-1783 najdeme zápis, který se týká tragického závěru Öttlova života. Potvrzuje

18 Je ovšem zvláštní, že o této záležitosti, která jistě nebyla pro Scherzera zanedbatelnou historkou, se vůbec nezmiňují ve své podrobné studii Blümmel a Gugitz. Ačkoliv vypočítávají v období let 1779-1781 mnohé jeho členy společnosti (mezi nimi mj. i Franze Vasbacha a skladatele a kapelníka Johanna Mederitsche), Öttlovo jméno se v textu studie nevyskytne (BLÜMMEL a GUGITZ 1925: 276-287). 
datum úmrtí 12. května 1781, které uvádí Pallestrazzi na poslední straně almanachu. Je zde uvedeno jméno kněze, který jej zaopatřil, i jméno kněze, který byl u pohřbu 15. května. Ředitelovo jméno je zapsáno foneticky jako Josephus de Etel Director Comediae... A pak údaj nejdůležitější: v kolonce věku zemřelého je uvedeno, že ředitel Öttl měl teprve 25 let. Tím se patrně dostatečně objasňuje, proč jeho jméno jako divadelního ředitele nezanechalo více stop v dějinách divadla, které by jinak důslední němečtí a rakouští bibliografové zachytili.

Bez zajímavosti jistě není, že v den úmrtí ředitele se v divadle hrálo: byla uvedena tříaktová veselohra Die Poeten nach der Mode (a na konci představení tančily Hasenhutovy děti Terzetto). Tento fakt lze vysvětlit pouze tím, že ředitel zemřel během nebo po představení, možná se jednalo o tragickou nehodu. Následující tři dny až do pohřbu zůstalo divadlo zavřeno, další představení se uskutečnilo 16. května.

Přestože máme poznatky pouze o několika členech Öttlovy společnosti, je snad možné aspoň do určité míry zobecňovat. Na první pohled badatele zaujme, že hned několik osobností prošlo společností Franze Scherzera během jejího působení ve vídeňském Josefstadtu v tzv. Bauernfeindovském sále na konci sedmdesátých let. Byli to přinejmenším Franz Vasbach, Joseph Hasenhut se syny, Johann Mederitsch a patrně tedy i Joseph von Öttl. To by mohlo svědčit o tom, že se Franz Scherzer opravdu dostal do finančních problémů, soubor se mu rozpadl a část členů odešla s „novým“ ředitelem Öttlem do Olomouce. Ve zmíněné životopisné studii o Franzi Scherzerovi se ovšem o něčem takovém nepíše, jeho pobyt v divadle $\mathrm{v}$ Josefstadtu měl pokračovat až do jara 1781 (BLÜMMEL a GUGITZ 1925: 284-285).

Z našich poznatků se potvrzuje, že velký podíl na utváření rakouského divadelního prostoru měla právě migrace osobností. Jen tento teritoriálně a časově velmi omezený výzkum v Olomouci prokazuje, jak byla tehdejší sít divadel propojena. Bezpochyby je nutné vzít na vědomí odlišné postavení a funkce divadel na Moravě a v Praze v období do roku 1918, kdy divadelní vývoj v rakouské monarchii určovala Vídeň.

A nakonec se snad můžeme, byt jen na základě znalosti menší části souboru, dopustit i hypotetické úvahy o charakteru Öttlovy společnosti. Vyjděme z generačního zařazení známých členů společnosti. Franz Vasbach měl třiadvacet let (přitom byl angažován pro obor komických starých!), jeho manželka pravděpodobně nebyla starší. Franz Seve byl osmadvacetiletý, věk jeho manželky neznáme. Johann Mederitsch přišel do Olomouce v devětadvaceti letech, ředitel Öttl zemřel v pětadvaceti, Hasenhutovi synové byli mladíci. Zdá se, že můžeme předpokládat soubor spíše mladších herců a zpěváků, někteří byli na začátku své dráhy, mohli bychom tedy očekávat mladou energii, dynamiku, osobní nasazení. Jednou z otázek, na které bychom rádi znali odpověd', je samozřejmě to, jak byly divadelní produkce Öttlovy - Pallestrazziho společnosti hodnoceny a přijímány olomouckým publikem. Ze soupisu denního repertoáru v roce 1781 a z prezentace společnosti v almanachu z Gothy (OLLMÜTZ 1782) vyplývá, že společnost hrála tři, nejvýše čtyři dny v týdnu. Hlediště městského divadla na Dolním náměstí mělo kapacitu asi 320-350 diváků. Pokud se přes léto hrálo v dřevěné boudě na Dolním náměstí, její hlediště bylo nepochybně ještě podstatně menší. Společnost měla po celou 
dobu kolem pětadvaceti členů, to byl středně velký divadelní podnik. Ǩeditel byl ekonomicky odkázán pouze na vybrané vstupné. Pallestrazzi po dvou letech, patrně na jaře 1783, z Olomouce odešel a můžeme se jen domýšlet, zda tomu tak bylo pro finanční potíže. Mohla by to naznačovat poznámka Christiana d'Elverta v jeho dějinách divadla na Moravě a ve Slezsku. Zmiňuje se o tom, že když ředitel Franz Scherzer přece jen v roce 1784 získal pronájem olomouckého divadla a navrhoval jeho stavební rozšíření, gubernium jeho žádost zamítlo z tohoto důvodu: „Wegen zu geringer Einnahme hatten die Unternehmer Rößel, Pauli, von Oettl und von Pallestrazzi das Theater Schulden halben verlassen müssen "(ELVERT 1852: 141-142).

Nemůžeme si být také jisti tím, zda a jak poměrně ambiciózní a moderní divadelní program přijímalo obyvatelstvo pevnostního města - je více poznatků i z velkých míst, že touha publika po improvizovaném divadle a po Hanswurstech barokní epochy byla vytrvalá a přivedla do finančních potíži mnohého ředitele s průbojným programem. Jedním z mála očitých svědků těch časů byl Johann Alexius Eckberger, pravděpodobně za pseudonymem skrytý muž, který několik let v Olomouci žil a tehdejší život ve městě popsal ve spisu, jenž vyšel v roce 1788 ve Vídni. Bohužel přišel do města nedlouho poté, co zde Pallestrazzi skončil, ale ve srovnání s následujícími řediteli stačil zaznamenat, že divadlo právě za jeho vedení mělo ve městě největší ohlas a že mnozí Olomoučané si přáli Pallestrazziho návrat. A učinil také zmínku o tom, že Pallestrazzi obětavě vložil do divadla celý svůj majetek (ECKBERGER 1998: 191-192).

$\mathrm{O}$ tom, že se společnosti v Olomouci spíše dařilo a že byla přinejmenším uvnitř soudržná, by naopak mohla svědčit jiná skutečnost, byt̉ nepř́ímo: stálost souboru. V té době byla fluktuace herců velmi vysoká a souvisela s tím, že každý věřil ve výhodnější angažmá u jiného ředitele. Během roku 1781 odešli od společnosti čtyři herci (a Hasenhutovi synové) a tři dámy, během následujícího roku, do podzimu 1782, pouze jediný herec a kapelník Mederitsch. Velká většina členů souboru z roku 1781 tedy zůstala v Olomouci i v sezoně 1782/1783 - to může svědčit o tom, že zdejší angažmá bylo pro ně prríznivé.

Prameny, které se dochovaly k olomouckým sezonám v letech 1781-1783, se jeví jako výjimečné pro naše vědomosti o raných počátcích městského divadla v Olomouci. Základní informace o repertoáru a členstvu divadla nám chybí nejen pro celé první desetiletí před Öttlovým prríchodem, ale i v dlouhém období po roce 1783: teprve pro leden až březen 1796, tedy závěr sezony 1795/1796 ředitele Carla Haina, máme opět k dispozici souvislejší přehled odehraného repertoáru, a to díky časopisu Allgemeines europäisches Journal z roku 1796.

Tato jedinečnost a nemožnost komparace v časoprostoru ovšem brání badateli v seriózním zobecnění. Př́liš se to nedaří ani ve srovnání s brněnským divadlem té doby. Jeho soupis repertoáru, pořízený Miladou Wurmovou pro nejbližší srovnatelné období let 1777-1784, je rovněž velmi kusý. Zahrnuje kolem padesáti titulů, z nichž asi deset se hrálo také v Olomouci během roku 1781, včetně dvou her Lessingových a dvou tragédií Shakespearových (WURMOVÁ 1996: 9-11). Na olomouckém repertoáru je patrná snaha direktora o co nejpestřejší nabídku žánrovou, ohledy na publikum jsou ale vyvažová- 
ny ambiciózními snahami: převládající počet frašek a veseloher byl střídán tragédiemi včetně Shakespearových (jeho komedie byly tehdy obecně pomíjeny). Dramatika byla velmi aktuální, v naprosté většině se jednalo o žijící autory, což ovšem jistě souviselo s nástupem osvícenských požadavků na nové pravidelné drama se soudobými tématy. Dramaturgický rozhled (nepochybně podložený bohatou knihovnou) by potvrzoval, že mladý Öttl strávil nějaký čas s ředitelem Scherzerem ve vídeňském Josefstadtu a důvěrně se zde s novými tendencemi seznámil, Pallestrazzi je pak posílil širším záběrem do zejména soudobé dramatiky francouzské. Společnost se snažila udržovat trvalý zájem diváků i nabídkou singspielů, pantomim, individuálních pěveckých, hereckých a tanečních výkonů (Seveovi, Hasenhutova rodina, árie zpěvačky Poschettiové).

Smlouva města Olomouce s Josephem von Öttlem o pronájmu městského divadla svědčí o tom, že radní si už plně uvědomovali význam řádně spravovaného divadla pro prestiž města. Brzy po vybudování městského divadelního sálu se snažili s řediteli dosáhnout víceletého pronájmu a provoz divadla tak stabilizovat - už v roce 1773, jak zaznamenal d'Elvert, uzavřeli tř́letou smlouvu s dvojicí ředitelů Koberwein Hellmann (ELVERT 1852: 141). Trvání smlouvy s Öttlem bylo stanoveno na dobu od 13. dubna 1781 do 15 . dubna 1784 . Konec sezony a začátek nové vymezovaly velikonoční svátky. Smlouva obsahovala ustanovení týkající se výše pronájmu a způsobu jeho uhrazení, využívání divadla během masopustu pro plesy a bály, používání dřevěného divadla postaveného na Dolním náměstí v jarním a letním období („Somerbau$d e^{\text {“) }}$, ručení za vybavení divadla, protipožárních opatření apod. Bez zajímavosti není, že v třetím oddíle smlouvy město vedlo ředitele $\mathrm{k}$ odpovědnosti za předvádění hodnotného repertoáru. Zdá se, že na počátku osmdesátých let 18. století mělo divadlo v Olomouci místo, které odpovídalo osvícenským požadavkům na nové společenské funkce divadla a které také odpovídalo významu postavení Olomouce jako donedávna hlavního města Moravy.

Nejslabším článkem této už významné městské instituce byl tedy pravděpodobně „pouze“ ne příliš vhodný divadelní sál, postavený nad masnými krámy produkujícími trvalý zápach, jak na to upozorňovali už mnozí současníci. ${ }^{20}$ Tento problém byl definitivně odstraněn až 4. října 1830, kdy byla na dnešním Horním náměstí otevřena velkoryse řešená nová divadelní budova architekta Josefa Kornhäusela, ve své době pokládaná za jedno z nejkrásnějších středoevropských divadel.

20 Např́klad Josef Leitmetzer se ve své kronice zmiňuje i o poměrně primitivním vybavení dřevěného sálu, které se brzy opotřebovalo při plesech a dalších zábavách, o hrozícím nebezpečí požáru atd. Viz (LEITMETZER 2001: 58-60). 


\section{Bibliografie}

ALTH, Minna von a Gertruda OBZYNA. 1977. Burgtheater 1776-1976. Aufführungen und Besetzungen von zweihundert Jahren. Bd. 1.-2. Wien: Ueberreuter, [1977].

ANTONICEK, Theophil. 1975. Mederitsch (Gallus) Johann. In Österreichisches Biographisches Lexikon 1815-1950. Bd. 6. Wien: Verlag der ÖAW, 1975: 183.

BLÜMMEL, Emil Karl a Gustav GUGITZ. 1925. Der Prinzipal Franz Scherzer. In Alt-Wiener Thespiskarren. Die Frühzeit der Wiener Vorstadtbühnen. Wien: Verlag von Anton Schroll \& Co., 1925: 271-307.

BRODSKÁ, Božena. 2006. Dějiny baletu v Čechách a na Moravě do roku 1945. Praha: Akademie múzických umění v Praze, 2006.

ČIČATKA, Jaroslav. 1955. Dějiny olomouckého divadla, doba nejstarší. Strojopis. Olomouc: Vědecká knihovna v Olomouci, [1955], sign. B II 291.170.

ECKBERGER, Johann Alexius. 1998. Charakteristische Beyträge zur Kenntniss der Hauptstadt und Gränzfestung Olmütz. - Př́spěvky k charakteristice a poznáni hlavního města a pohranični peunosti Olomouce. Olomouc: Memoria, 1998.

ELVERT, Christian d'. 1852. Die Geschichte des Theaters in Mähren und Oestr. Schlesien. Brünn: 1852.

HANSEN, Günther. 1969. Hasenhut, Anton. Hasenhut, Philipp Karl. In Neue Deutsche Biographie. Bd. 8. Berlin: Duncker \& Humblot, 1969: 31-32.

HAVLÍČKOVÁ, Margita. 2005. Baroko kontra osvícenství. Střetnutí dvou epoch v Městském divadle na Zelném trhu v Brně. In Eva Šormová a Michaela Kuklová (eds.). Miscellanea. Praha: Divadelní ústav, 2005: 221-228.

HAVLÍČKOVÁ, Margita, Sylva PRACNÁ a Jiří ŠTEFANIDES. 2011. Německojazyčné divadlo na Moravě a ve Slezsku. Ředitelé městských divadel. 1/3. Olomouc: UP, 2011.

HAVLÍČKOVÁ, Margita, Sylva PRACNÁ a Jiří ŠTEFANIDES. 2013. Německojazyčné divadlo na Moravě a ve Slezsku. 2/3. Olomouc: UP, 2013.

JAKUBCOVÁ, Alena a Matthias J. PERNERSTORFER (eds.). 2013. Theater in Böhmen, Mähren und Schlesien. Von den Anfängen bis zum Ausgang des 18. Jahrhunderts. Ein Lexikon. Wien: Verlag der Österreichischen Akademie der Wissenschaften, 2013.

KOMORZYNSKI, Egon von. 1904. Gallus, Johann. In Allgemeine Deutsche Biographie. Bd. 49. Leipzig: Duncker \& Humblot, 1904: 245-248.

KOPECKÝ, Jiří. 2012. Německá operni scéna v Olomouci 1770-1878. Olomouc: UP, 2012.

KUX, Johann. 1937. Geschichte der königlichen Hauptstadt Olmütz bis zum Umsturz 1918. Reichenberg/Olmütz: Verlag der Anstalt für Sudetendeutsche Heimatforschung - Verlag Franz Kraus Reichenberg, 1937.

LEITMETZER, Josef. 2001. Leitmetzerova olomoucká kronika z let 1778-1829. Olomouc: Memoria, 2001.

MIKULÁŠ, Jiří. 2002. Kozácký tábor na Starém Městě pražském L.P. 1785. Divadelni revue 23 (2002): 3: 89.

OLLMÜTZ. 1782. Ollmütz. In Theater-Kalender auf das Jahr 1783. Gotha, 1782: 272-274.

PIES, Eike. 1973. Prinzipale. Zur Genealogie des deutschsprachigen Berufstheaters vom 17. bis 19. Jahrhundert. Ratingen/Kastellaun/Düsseldorf: Aloys Henn Verlag, 1973.

PROCHÁZKA, Vladimír (ed.). 1988. Národni divadlo a jeho předchưdci. Praha: Academia, 1988.

SOAO. 1781a. Státní okresní archiv v Olomouci. Smlouva mezi magistrátem a řed. Josephem Oettlem. Archiv města Olomouce, Zlomky registratur 1426-1786, inv. č. 810. 
SOAO. 1781b. Státní okresní archiv v Olomouci. Úmrtní matrika Vnitřní město, 1759-1783, inv. č. 5608, sign. O III 26, s. 236.

ULRICH, Paul S. 1997. Bibliographisches Verzeichnis für Theater, Tanz und Musik. Bd. 1-2. Berlin: Verlag Arno Spitz GmBH, 1997.

ULRICH, Paul S. 2019. Deutschsprachiges Theater in Tschechien (1777-1918). Bd. 1-2. Wien: Don Juan Archiv, 2019. (Pracovní verze.)

VKOL. 1781. Vědecká knihovna v Olomouci. Theater-Taschenbuch von 21. Jenner bis Ende Dec. 1781 aller von der allhiesigen deutschen Schauspielergesellschaft in Ollmütz aufgeführten Schau- und Singspielen. Zum Neuen Jahrs-Geschenke zusammengetragen. Olomouc: 1781, sign. 47445.

WURMOVÁ, Milada. 1996. Repertoár brněnského divadla v letech 1777-1848. Brno: ŠIFRA, 1996.

\section{Doc. PhDr. Jiř́ Štefanides}

Katedra divadelních a filmových studií, Filozofická fakulta, Univerzita Palackého Univerzitní 3, 77180 Olomouc, Česká republika jiri.stefanides@upol.cz

Jiří Štefanides přednáší v Olomouci dějiny českého divadla. Badatelsky se zabývá dějinami německojazyčného a česky hraného divadla na Moravě a ve Slezsku v 18.-20. století. V letech 2006-2008 vedl tř́členný tým, který v osmnácti moravských a slezských městech České republiky identifikoval deset městských divadel s německy hrajícím souborem, jež existovala $\checkmark$ letech 1733-1944. S kolektivem autorů připravil Kalendárium dějin divadla v Olomouci (od roku 1479), je autorem monografie České divadlo v Moravské Ostravě 1908-1919 a dalších publikací. 